\title{
ECTODERMAL DYSPLASIAS REVISITED
}

\author{
NEWTON FREIRE-MAIA
}

Department of Genetics, Federal University of Paraná, Curitiba, Paraná, Brazil

This paper presents a historical view of the development of the concept of ectodermal dysplasia, analyses five current " definitions" of the group, and classifies 52-57 ectodermal dysplasias into subgroups on the basis of criteria developed by the Author.

\section{INTRODUCTION}

Ectodermal dysplasias (EDs) form a large, heterogeneous and increasing nosologic group. Every year, new syndromes are described and labelled as EDs. A few years ago, with the intention of reducing the chaotic aspect that the field was gaining, we proposed a clinical definition and a clinical-mnemonic classification of EDs (Freire-Maia 1971). Since that time, two other reviews were published (Settineri 1974, Witkop et al. 1975), a "community of diseases" was described within EDs (Pinsky 1975), and the group was enlarged with the inclusion of some " new" syndromes.

In our 1971 paper, we mentioned 32 EDs. Now that our list includes 52-57, we decided to revisit the subject in order to present a historical analysis and a new clinical overview of EDs as classified into subgroups.

\section{" HEREDITARY ECTODERMAL DYSPLASIA"}

The expression " hereditary ectodermal dysplasia" (HED) was suggested by Weech (1929) to substitute for other expressions such as "dystrophy of the hair and nails", " imperfect development of skin, hair and teeth", "congenital ectodermal defect", etc., used to cover a small group of diseases having, as cardinal signs, hypotrichosis, hypodontia, onychodysplasia and "anhidrosis", or only some of them. According to Weech, the new expression applied to the three essential features of these conditions: (1) most of the disturbances affect tissues of ectodermal origin; (2) these disturbances are developmental; (3) heredity plays an important etiological role.

The best known of these conditions was a syndrome (the " anhidrotic form ") now widely known under the multiple eponymic designation of Christ-Siemens-Touraine (CST), which is additionally characterized by characteristic facies with saddle nose and protruding lips, chronic rhinitis and pharyngitis associated with a decrease of taste and smell, hearing loss, etc.

This "form " was generally reported as due to a " recessive" sex-linked gene. Weech (1929) stated that "were no more to be said, it would seem that the inheritance data just given 
would be in themselves sufficient to separate the anhidrotic from other forms of ectodermal dysplasia " (p. 785). From a clinical point of view, Weech cites several features "favouring such a division" in the teeth, the sudoriparous glands, the nails, etc. On the same and in the following pages, Weech notes, however, that full-blown cases of the so-called " anhidrotic form" (previously called " anhidrosis hypotrichotica sexoligata" by Siemens (1921) have been found, sometimes, in females. He points out that this fact " does much to weaken the full acceptance of the sex-linked character of the inheritance in the anhidrotic group". And, on page 787, he confesses that " an adequate explanation for the occurrence of the anhidrotic syndrome in the female is not possible". Now we know that what he called the "anhidrotic syndrome" is, in reality, a group of at least two syndromes, one being due to an X-linked gene (which may present mild expression in heterozygous females) - the Christ-Siemens-Touraine syndrome, and the other due to the homozygous state of an autosomal recessive gene - autosomal recessive hypohidrotic ectodermal dysplasia (Passarge et al. 1966, Gorlin et al. 1970).

\section{WHAT IS AN ECTODERMAL DYSPLASIA?}

The first cases of CST reported in the literature seem to be those described in a Hindu family by Wedderburn in 1838 . The same kindred was mentioned in 1875 by Charles Darwin. Subsequently, other investigators described clinically similar cases in a large number of families, thus creating the problem of their clinical and etiological delineation (reviews in Weech 1929, Touraine 1932 and 1952, Upshaw and Montgomery 1949, Franceschetti 1953, Rosselli and Gulienetti 1961, Greene 1962, Montgomery 1967, Gorlin et al. 1970, Freire-Maia 1971, Bergsma 1973, Settineri 1974, Witkop et al. 1975; see also Durham 1960, Rubin 1967, Jablonsky 1969). Cardinal signs, associated signs and general symptoms have been recognized; severe, moderately severe, and mild states have been identified; "incomplete syndromes" and "variants" have been described. The "cardinal" signs and some of the most common " associated" signs, represented by affections of tissues of ectodermal origin, justified the general expression covering the group. The high clinical heterogeneity verified in the group, together with an etiological heterogeneity also clearly seen, showed, however, that we were dealing with a number of different - in spite of somewhat clinically similar conditions rather than with a few highly variable conditions. With time, this opinion became very well established and, as the number and variability of the "associated" signs (many of which affected tissues not of ectodermal origin) increased and some of the "cardinal" ones were not always found, the complexity of the nosologic group appeared larger and larger. Touraine (1932) suggested the expression " ectodermal polydysplasia " for the former " anhidrotic form", in order to call attention to the extensive polysymptomatology involved. As mentioned, forms were first classified into two groups, anhidrotic and hidrotic, but it was also seen that hypotrichosis, dental defects and onychodysplasia could as well be lacking. At this point, naturally, even the expression " ectodermal dysplasia " started to lose its early clear signification. How many ectodermal signs - and which ones - must a syndrome have to be classified as an ectodermal dysplasia? Should any syndrome with one sign affecting the hair or the teeth or the epidermis be designated an ectodermal dysplasia? If this would be so, the number of "ectodermal dysplasias" would be so large that the expression would entirely lose its practical interest. Then the syndrome should have two, three, four " ectodermal " signs? But which combinations of signs should be accepted as a criterion of classi- 
fication? In other words, what clinical aspects must a condition take to be accepted as an "ectodermal dysplasia"? As regards sweating capacity, we may face euhidrosis (normal sweating), hypohidrosis, and hyperhidrosis. As regards dental defects, hypodontia may be rather different from one syndrome to the other, according to the teeth involved and other characteristics (persistence of deciduous, absence of permanents, early caries, etc.). As regards trichodysplasia, both hypotrichosis and hypertrichosis may occur in different degrees. The same kind of variability is found as regards onychodysplasia. Weech (1929), for instance, had already noted that the nail defect of the condition described and reviewed by Jacobsen (1928) was never seen in his " anhidrotic form ".

What then is an ectodermal dysplasia? The answer will vary from author to author. It may be:

(1) One disease;

(2) A group of two well-defined diseases;

(3) A group of two " main" diseases with some heterogeneity;

(4) A group of a few diseases;

(5) A large group of diseases.

1. One disease, the sex-linked "recessive" classical hypohidrotic form (CST syndrome) (cf. Dominok and Rönisch 1968, Bollaert and Wachholder 1969, Agostinelli 1970).

2. A group of two well-defined and clearly differentiated diseases, each of them without any internal etiological heterogeneity. This concept is accepted in a review of the literature by Blattner (1968), where one of the types is due to a " recessive" X-linked gene with some manifestation in the heterozygous females (the CST syndrome), and the other to an autosomal dominant gene (the Clouston syndrome). The former is mentioned, as in many other papers, as the " anhidrotic type", and the latter as the "hidrotic type". Both are said to represent different forms of a " familial syndrome associated with ectodermal dysplasia". This concept seems similar to, but not identical with, that developed for the "first arch syndrome" by McKenzie (1958).

3. A group of two " main" diseases, the anhidrotic and the hidrotic forms, with some heterogeneity (see, e.g., Clouston 1939). This concept may be summarized with the words of Robinson et al. (1962):

Cases of hereditary ectodermal dysplasia tend to fall into two groups, the hidrotic and anhidrotic forms. They share common abnormalities of the teeth, nails, and hair, one or all of which may be expressed in a single individual, but they are determined by different genetic mechanisms. The hidrotic form usually results from the action of an autosomal dominant gene, whereas the anhidrotic form appears to be determined by the action of a sex-linked recessive gene (p. 797).

The " hidrotic form" is the Clouston syndrome; the " anhidrotic form" is the CST syndrome. In the paper from which these introductory words have been obtained, what "appears to be a new syndrome" belonging to the hidrotic-autosomal dominant form is described (the Robinson syndrome).

The same concept may be seen in Lowry et al. (1966), where a family of French-Canadian origin with a number of cases of the Clouston syndrome is analysed. The authors point out that " the hidrotic type curiously occurs largely in persons of French descent" (p. 395). 
The same pedigree showing Robinson syndrome is also presented again. The authors state that "the variable expressivity of the hidrotic form is illustrated in our cases" (p. 398), whereas it would be better to recognize that they were dealing with two different diseases. The authors recognize, however, the existence of other " variants" of ED (p. 400).

Another example of a binary nomenclature may be seen in Samuelson (1970). For him, ectodermal dysplasia equals CST syndrome, but he also states that "Ellis-van Creveld's syndrome is a variant of anhidrotic ectodermal dysplasia" (p. 98) and refers to Böök syndrome as a "hidrotic ectodermal dysplasia", pointing out that the patients with this syndrome have hyperhidrosis (p. 98). According to this view, we would also have two " main " diseases inside the group, one characterized by anhidrosis (with a "variant") and the other by hyperhidrosis.

A binary clinical and etiological view of ED may also be seen in the paper by Machtens et al. (1972), for whom two different forms may be differentiated, in spite of the well-known variability as regards clinical appearance and mode of inheritance.

4. A group of a few diseases, such as defined by Weech in 1929 (see also Greene 1962 and Smith 1969 and 1970). Smith (1969) mentions, as ED, the following eight conditions: CST, Marshall's, Robinson's Feinmesser's, Clouston's, Basan's, Enamel hypoplasia and curly hair, and Pili torti and deafness. CST is referred as "Hypohidrotic ectodermal dysplasia" and Clouston's is mispelled as Clouson's.

According to Salomon and Esterly (1973), since the expression ED has been used to designate two well-delineated diseases (CST and Clouston syndromes), it should not indiscriminately and inaccurately be extended to cover any syndrome with a sign complex involving structures of ectodermal origin. These authors describe, however, five syndromes under the heading of ED: Hypohidrotic ED (CST); Hidrotic ED, i.e., Clouston syndrome (they accept that Robinson syndrome may be a "variant" of it); EEC (ectrodactyly-ectodermal dysplasiacleft lip and palate), Ellis-van Creveld syndrome; and Congenital ectodermal dysplasia of the face.

5. A large group of diseases (Freire-Maia 1971, Settineri 1974, Witkop et al. 1975, Pinsky 1975).

A pathogenetic definition of ectodermal dysplasia is a developmental defect which, at the embryological level, affects the ectoderm. Clinically, it is represented by a group of conditions with signs in tissues of ectodermal origin, and generally also in structures of nonectodermal origin, as mentioned earlier. This means that, under the heading of " ectodermal dysplasias ", there are pure monodysplasias, pure polydysplasias and malformation/dysplasia syndromes, according to the recent nomenclature of Herrmann et al. (1975). And since, according to the occurrence of the primary defect early or later during the embryological development, the condition may vary in extent and severity (Greene 1962), the same disease may show a high clinical variability.

Some of the syndromes that will be listed here as ectodermal dysplasias have been classified under a totally different heading by Smith (1970): Hallerman-Streiff's ("Unusually small stature with associated defects"); Oculodentodigital dysplasia ("Oral-facial-digital associations of defects "); Goltz-Gorlin's; Rothmund-Thomson's; Dyskeratosis congenita and incontinentia pigmenti ("Hamartoses"); and Ellis-van Creveld's ("Osteochondrodysplasias"). This is, as mentioned by Smith, an arbitrary classification, as classifications of 
diseases sometimes are. Classifications based on profound pathogenic similarities, such as that of mucopolysaccharidoses, for instance, have, however, a general clinical resemblance that derives from a real common basis. The diseases so classified really form a " community" or "family" (Pinsky 1975, Freire-Maia 1977).

\section{A DEFINITION AND CLASSIFICATION OF ECTODERMAL DYSPLASIAS}

Here (as suggested previously: Freire-Maia 1971), ectodermal dysplasias are defined as conditions with at least one of the signs related to those verified in the first cases - trichodysplasia, dental defects, onychodysplasia, and dyshidrosis — plus at least one sign affecting other structures of ectodermal origin. This is, naturally, an artificial definition so formulated with the only intention of delineating the field. Therefore, conditions affecting only, say, the skin and the oral mucosa (ichthyosis congenita), which have been already classified as ectodermal dysplasias (Greene 1962), will not be covered by our definition.

Our words above should not be interpreted as meaning that any anomaly affecting, say, the teeth, the nails, the hair and the skin (e.g., acrodermatitis enteropathica and congenital porphiria) will be called here ED. It is implied that the clinical signs verified in those regions have derived from what is supposed to be a primary ectodermal defect and are not accompanied by other nonectodermal but much more striking signs. A large dose of personal preferences may be, therefore, responsible for the way a given disease is classified, as in the present case.

As already mentioned, ectodermal dysplasias are not, generally, complexes of signs of a purely ectodermal origin. The old concept of " one layer disease" is no more acceptable (Rosselli and Gulienetti 1961), since these syndromes are generally characterized by constellations of signs of multiple embryological origin. The original name remains only because of historical considerations and because the ectodermal defects are either more severe or more apparent than the others.

Nomenclature is highly confusing in this field. Different eponyms side by side with different descriptive names for the same syndrome created an extensive nomenclature for a few situations. Gorlin and Pindborg (1964, 1976), Jablonski (1969), and Smith (1970), among many others, should be consulted in any case of doubt.

The Table lists 52 conditions with at least two of the four above-mentioned signs (a review of them is being written by Freire-Maia et al. 1977).

These conditions (Group A) are classified according to number and kinds of these signs: trichodysplasia (1), dental defect (2), onychodysplasia (3), and dyshidrosis (4). The different subgroups may be called either by the combination of the numbers shown in the Table (e.g., $1-2-3-4,1-2-3$, etc.) or by the combination of words of Greek origin referring to the structures showing the disturbances:

1-2-3-4: tricho-odonto-onycho-dyshidrotic subgroup (when referring to a specific disease, the word dyshidrotic may be replaced by hypo- or hyperhidrotic; e.g., Christ-Siemens-Touraine Syndrome is a tricho-odonto-onycho-hypohidrotic disease);

1-2-3: tricho-odonto-onychic subgroup;

1-2-4: tricho-odonto-dyshidrotic subgroup;

1-3-4: tricho-onycho-dyshidrotic subgroup;

2-3-4: odonto-onycho-dyshidrotic subgroup; 
Table. List of EDs as classified into subgroups, with indication of etiology and synonyms

Ectodermal dysplasias*

Synonyms

\section{Subgroup 1-2-3-4**}

1. Christ-Siemens-Touraine (SDX)

2. Autosomal recessive hypohidrotic ED (AR)

3. Goltz-Gorlin (DX?)

4. Xeroderma-talipes and enamel defect (XTE) (AD)

5. Rosselli-Gulienetti (AR)

6. Dyskeratosis congenita (AD and RX; het.)

7. Pachyonychia congenita (AD)

8. Rapp-Hodgkin (AD)

9. Ectrodactyly-ED-clefting (EEC) (AD)
Siemens s.; Weech s.; Jacquet s.; Anhidrosis-hypotrichosis-anodontia s.; Anhidrotic hereditary ED; Hereditary ectodermal polydysplasia; Hypohidrotic $\mathrm{X}$-linked ED.

Goltz s.; Focal dermal hypoplasia s. (FDH); Focal dermal dysplasia s.

Zinsser-Engman-Cole s.; Cole-Rauschkolb-Toomey s.; Zinsser s.; Cole s.

Jadasshon-Lewandowski s.; Pachyonychia ichthyosiforme; Polykeratosis congenita; Pachyonychia congenita, type I; idem, type II; idem, type III.

Hypohidrotic ED with cleft lip, palate, ocular, genital and digital anomalies.

Ectrodactyly-ED-cleft lip and palate.

\section{Subgroup 1-2-3}

10. Rothmund-Thomson (AR)

11. Fischer-Jacobsen-Clouston (AD)

12. Coffin-Siris (?)

13. Tooth and nail (AD)

14. Enamel hypoplasia and curly hair (AD)

15. Tricho-rhino-phalangeal (AR and AD; het.)

16. Incontinentia pigmenti (classical form) (DX?)

17. Ellis-van Creveld (AR)

18. Schöpf-Schulz-Passarge (AR)

19. Dento-oculo-cutaneous (AD ?)

20. Odontotrichomelic dysplasia (AR ?)

21. Fried tooth and nail (AR)

22. Sensenbrenner-Dorst-Owens (?)
Rothmund s.; Rothmund-Petges-Cléjat s.; Rothmund dystrophy; Petges-Cléjat s.; Congenital poikiloderma and juvenile cataract s.; Dyshormonal dermatosis of Bloch and Stauffer; Poikiloderma congenitale; Telangiectasis-pigmentation-cataract $\mathrm{s}$. Hidrotic ED; ED (ungueal type); Waldeyer-Fischer s.; Clouston s.; Jacobsen s.

Mental retardation with absent fifth fingernail and terminal phalanx.

Witkop s.; Witkop-Weech-Giansanti s.

Tricho-dento-osseous (TDO) s.; taurodontismamelogenesis imperfecta-kinky hair; AD hypoplastic enamel with hair and nail defect; Robinson-MillerWorth s.

Bloch-Sulzberger s.; Bloch-Siemens s.; Dermatose pigmentaire; Melanoblastosis cutis linearis.

Chondroectodermal dysplasia; Mesoectodermal dysplasia; Chondrodysplasia tridermica.

Palmoplantar keratosis, hypodontia, hypotrichosis and cysts of eyelids.

Freire-Maia s.; Tetramelic ED.

\section{Subgroup 1-2-4}

23. Böök (AD)

24. Lenz (DX)

25. Regional ED with total bilateral cleft (?)
PHC s. (premolar aplasia-hiperhidrosis-canities prematura s.); Premolar aplasia-hyperhidrosispremature greying $\mathrm{s}$.

\section{Subgroup 1-3-4}

26. Fischer (AD)

27. Trichodysplasia-onychogryposis-hypohidrosisFreire-Maia s. cataract (?)

28. Alopecia-onychodysplasia-hypohidrosis-deafness (AR?)

29. Wilson-Grayson-Pieroni (?) 
Subgroup 2-3-4

30. Hypoplastic enamel-onycholysis-hypohidrosis (AD)

\section{Subgroup 1-2}

31. Gorlin-Chaudhry-Moss (AR?)

32. Hallermann-Streiff (AD?)

33. Oculodentodigital (ODD) (AD and AR ? het.)

34. Moniletrix and anodontia (AD)

35. Orodigitofacial (DX?)

36. Hair defect-malposition of teeth-gengival fibromatosis (AR ?)

37. Walbaum-Dehaene-Schlemmer (AR)

38. Mikaelian (AR)

39. Stoy-Stenvick (AR?)

40. Hypertrichosis lanuginosa (AD)

41. Berlin (AR) (1-2-4?)

\section{Gorlin s.}

Ullrich and Fremerey-Dohna s.; Hallermann-StreiffFrançois s.; François dyscephaly; Oculo-mandibulo-dyscephaly with hypotrichosis; Mandibulo-oculofacial dysmorphism.

Meyer-Schwickerath and Weyers s.; Gillespie s.; Microphthalmos s.; Dysplasia oculo-dento-digitalis.

Papillon-Léage and Psaume s.; Dysplasia linguofacialis; Oro-facial-digital s. (OFD); Oro-digito-facial dysostosis; Gorlin-Psaume s.

Congenital ED with hearing loss.

Congenital hypertrichosis lanuginosa $\mathbf{s}$.

Melanoleucoderma s.

\section{Subgroup 1-3}

42. Chands (AD)

43. Familial hypertrichosis cubiti (AR ?)

44. Palmoplantar hyperkeratosis and alopecia (AD and $A R$; het.)

45. Onychotrichodysplasia with neutropenia (AR)
Curly hair-ankyloblepharon-nail dysplasia s.

Hairy elbows s.

\section{Subgroup $1-4$}

46. Congenital ED of the face (AD; AR ?; het.)

47. Spiny hyperkeratosis, alopecia and deafness (?) (1-3-4?)
Focal facial-dermal-dysplasia; Facial ED.

Generalized spiny hyperkeratosis, universal alopecia and deafness.

\section{Subgroup 2-3}

48. Robinson (AD)

Ectodermal dysplasia and deafness.

49. Baisch (AR)

50. Triphalangeal thumbs-hypoplastic distal phalanges-onychodystrophy (AR ?)

\section{Subgroup 2-4}

\section{Marshall? (AD)}

52. Naegeli-Franceschetti-Jadasshon (AD)
ED with ocular and hearing defect; ED, deafness and ocular anomalies.

Franceschetti-Jadasshon s.; Naegeli incontinentia pigmenti; Reticular pigmented dermatosis; Palmoplantar hyperkeratosis with reticular pigmentation.

* Information on most of these syndromes may be seen in Franceschetti (1953), Durham (1960), Greene (1962), Gorlin and Pindborg (1964, 1976), Rubin (1967), Jablonski (1969), Smith (1969, 1970), Freire-Maia (1971), Bergsma (1973), Settineri (1974), Witkop et al. (1975), Pinsky (1975), and Freire-Maia et al. (1977).

** $1=$ trichodysplasia; $2=$ abnormal dentition; $3=$ onychodysplasia; $4=$ dyshidrosis.

$\mathrm{AD}=$ autosomal dominant $\mathrm{AR}=$ autosomal recessive; $\mathrm{SDX}=\mathrm{X}$-linked semidominant $\mathrm{DX}=\mathrm{X}$-linked dominant. Question mark indicates either unkown etiology or that the corresponding information is doubtful. Indications of two etiologies for the "same" syndrome suggest heterogeneity (het.). 
1-2: tricho-odontic subgroup;

1-3: tricho-onychic subgroup;

1-4: tricho-dyshidrotic subgroup;

2-3: odonto-onychic subgroup;

2-4: odonto-dyshidrotic subgroup;

3-4: onycho-dyshidrotic subgroup.

Conditions with at least one of the four above-mentioned signs plus at least another sign in structures of ectodermal origin (labelled 5) are classified in another group (Group B). These conditions may be called either by the combination of the respective numbers or by the words of Greek origin referring to one of the four basic signs. Feinmesser and Basan syndromes, for instance, belong to the 3-5 subgroup or to the onychic subgroup; pili torti and deafness to the 1-5 subgroup, etc. Group B is much smaller (and therefore less important) than Group A; for this reason, our attention is much more directed to the latter than to the former.

Both for the conditions of Group A and B, the subgroups may also be called by the corresponding terms of any vernacular language. Examples: hair-tooth-nail subgroup (for 1-2-3), nail subgroup (for 3-5), etc.

Many other syndromes could be classified in the 1-2 subgroup, but convenience, based on a good knowledge of their pathogenesis, suggests that they should better be classified in other groups. For instance: Hurler's, Hunter's and Sanfilippo's are to be maintained among mucopolysaccharidoses; Treacher Collins' (mandibulofacial dysostosis) among the craniofacial dysostoses; etc. By the same token, the cri-du-chat syndrome (1-5), Crouzon paradrome (= anomalad) (2-5), homocystinuria (1-2), hyalinosis cutis et mucosae (1-2), Menkes syndrome (1-5), oculocutaneous albinism (1-5), osteogenesis imperfecta (2-5), pachydermoperiostosis (4-5), progeria (1-2-3), Seckel's bird-headed dwarfism (1-5), Sjögren-Larsson syndrome (1-2-4), Werner's (1-5), and many others, should preferably be maintained outside EDs and classified in other more suitable groups. On the same way, it may happen that some of the syndromes here listed as ED be later dislocated to other groups. Our classification may be, therefore, accepted both as incomplete and too loaded. Being a purely clinicalmnemonic classification, it is hoped that it be changed as we progress in the knowledge of the pathogenesis of each syndrome. (On the above-mentioned syndromes, see especially Smith 1970, and Goodman and Gorlin 1970.)

Epidermolysis bullosa (EB) is a group of conditions characterized by bulla formation and that differ from each other as regards clinical features, severity, frequency and etiology. Different numbers (from two to about ten) of " diseases", "forms ", " syndromes ", or " general forms", have been described under the heading of EB by different authors (for reviews, classifications, cases reports, etc., see, e.g. Gorlin and Pindborg 1964 and 1976, Passarge 1965, Davison 1965, Bart et al. 1966, Schnyder 1967, Gedde-Dahl Jr. 1971, Howden and Oldenburg 1972, and Joensen 1973). Some of the forms could be classified as ED on purely clinical grounds, but since all of them form a well-delineated group, it seems preferable, contrary to our first impression (Freire-Maia 1971), to keep the whole group untouched. As regards incontinentia pigmenti, since some of the most apparent cardinal signs are related to the skin (patches of vesicles, inflammatory lesions, pigmented macules, hyperkeratotic areas, etc.), it would seem preferable to keep it outside ED. Since, however, there is no other better group to include it, we'll keep it in the subgroup 1-2-3. 
Our classification is also subject to revision both due to mistakes and to the fact that some diseases may have not been fully investigated. Since, for instance, specific methods have not always been applied to evaluate the sweating capacity of the patients, one or more diseases presented as euhidrotic may be really dyshidrotic and, then, move to another group. The fact that some diseases have been described mainly in children or in a small number of adult patients, some of which belonging to the same family, may also be responsible for a too narrow delineation of them. Finally, it deserves to be mentioned that heterogeneity may be present in a larger number of syndromes than those mentioned.

Our list of ectodermal dysplasias shows a high degree of clinical and genetical heterogeneity. As regards etiology, the 57 (if the indicated heterogeneity will prove to be true) syndromes listed in Group A (Table) may be distributed, with different degrees of reliability, as follows:

- Autosomal dominants: $21-22$ cases $(37-39 \%)$

- Autosomal recessives: $14-23$ cases $(25-40 \%)$

- X-linked recessives: 1 case $(2 \%)$;

- X-linked dominants: $1-4$ cases $(2-7 \%)$;

- X-linked semidominants: 1 case $(2 \%)$

- Unknown etiology: 6-19 cases (11-33\%).

A detailed analysis of this distribution will be presented in a paper now in preparation (FreireMaia et al. 1977). I just would like to mention here that the distinction of the three categories of X-linked genes is subject to a complete review.

\section{CONCLUSION}

The importance of the classification of diseases into groups as regards didactic, differential diagnosis and research purposes is undeniable. Nosologic grouping is based on similarities among diseases. As these similarities may be clinical (at different levels), pathogenic, etiological, etc., nosologic groups may range from entirely artificial to real "communities" or "families" of diseases (Pinsky 1975, Freire-Maia 1977).

Ectodermal dysplasias, as delineated and classified in the present paper, represent obviously an artificial array of conditions lumped together simply because they share some similar clinical signs in tissues of ectodermal origin. Since no " natural " classification is available, the present one is to be accepted as a provisional one. In spite of this limitation, it proved already to be useful for differential diagnosis, didactic and research purposes.

\section{Acknowledgments}

I am very grateful to Drs. John M. Opitz and Eleidi A. Chautard-Freire-Maia for a critical reading of the manuscript. Thanks are also due to Mrs. Raquel Rapone-Gaidzinsky for help in the preparation of the table.

\section{REFERENCES}

Agostinelli O. 1970. La controdisplasia ectodermica di Ellis-van Creveld. Gazz. Int. Med. Chir., 75: 131-153.

Bart B.J., Gorlin R.J., Anderson V.E., Lynch F.W. 1966. Congenital localized absence of skin and associated abnormalities resembling epidermolysis bullosa. Arch. Dermatol., 93: 296-304.
Bergsma D. (ed.) 1973. Birth Defects. Atlas and Compendium. New York: National Foundation March of Dimes, White Plains.

Blattner R.J. 1968. Hereditary ectodermal dysplasia. J. Pediatr., 73: 444-447.

Bollaert A., Wachholder A. 1969. Dysplasie ectodermique. J. Belge Radiol., 52: 201-209. 
Clouston H.R. 1939. The major forms of hereditary ectodermal dysplasia. Can. Med. Assoc. J., 40: 1-7.

Davison B.C.C. 1965. Epidermolysis bullosa. J. Med. Genet., 2: 221-308.

Dominok G.W., Rönisch P. 1968. Histologische Hautbefunde bei ektodermaler Dysplasie von anhydrotischen Typ. Dermatol. Wochenschr., 154: 774-778.

Durham R.H. 1960. Encyclopedia of Medical Syndromes. New York: Paul B. Hoeber.

Franceschetti A. 1953. Les dysplasies ectodermiques et les syndromes héréditaires apparentés. Dermatologica, 106: 129-156.

Freire-Maia N. 1971. Ectodermal dysplasias. Hum. Hered., 21 : 309-312.

Freire-Maia N. 1977. Nosologic groups - An overview. Hum. Hered. (in press).

Freire-Maia N., Rapone-Gaidzinski R., Pinheiro M. 1977. Ectodermal dysplasias - A review. (MS).

Gedde-Dahl Jr. T. 1971. Epidermolysis Bullosa. A Clinical, Genetic and Epidemiological Study. Baltimore: Johns Hopkins Press.

Goodman R.M., Gorlin R.J. 1970. The Face in Genetic Disorders. Saint Louis: The C.V. Mosby Co.

Gorlin R.J., Pindborg J.J. 1964. Syndromes of the Head and Neck. New York: McGraw Hill Book Co.

Gorlin R.J., Old T., Anderson V.E. 1970. Hypohidrotic ectodermal dysplasia in females. A critical analysis and argument for genetic heterogeneity. Z. Kinderheilkd., 108: 1-11.

Gorlin R.J., Pindborg J.J. 1976. Syndromes of the Head and Neck. New York: McGraw Hill Book Co.

Greene G.W. 1962. Genetic factors in ectodermal dysplasias. In Carl J. Witkop (ed.): Genetics and Dental Health [pp. 161-170]. New York: McGraw-Hill Book Co.

Herrmann J., Gilbert E.F., Opitz J.M. 1975. Dysplasia, malformations and cancer, especially with respect to the Wiedemann-Beckwith syndrome. (MS).

Howden E.F., Oldenburg Th. R. 1972. Epidermolysis bullosa dystrophica: Report of two cases. JADA, 85: 1113-1118.

Jablonski S. 1969. Illustrated Dictionary of Eponymic Syndromes and Diseases and Their Synonyms. Philadelphia: W.B. Saunders Co.

Jacobsen A.W. 1928. Hereditary dystrophy of the hair and nails. JAMA, 90: 686-689.

Joensen H.D. 1973. Epidermolysis bullosa dystrophica dominans in two families in the Faroe Islands. A clinico-genetic study of 56 living individuals. Acta Dermatol., 53: 53-60.

Lowry R.B., Robinson G.C., Miller J.R. 1966. Hereditary ectodermal dysplasia. Symptoms, inheritance patterns, differential diagnosis, management. Clin. Pediatr., 5: 395-402.

Machtens E., von Weyhrother H.-G., Brands Th., Marxhors R. 1972. Klinische Aspecte der ektodermalen Dysplasie. Z. Kinderheilkd., 112: 265-280.
McKenzie J. 1958. The first arch syndrome. Arch. Dis. Child., 33: 477-486.

Montgomery H. 1967. Dermatopathology. New York: Harper \& Row.

Passarge E. 1965. Epidermolysis bullosa hereditaria simplex. A kindred affected in 4 generations. J. Pediatr., 67: 819-825.

Passarge E., Nuzum C.T., Schubert W.K. 1966. Anhidrotic ectodermal dysplasia as autosomal recessive trait in an inbred kindred. Humangenetik, 3: 181-185.

Pinsky L. 1975. The community of human malformation syndromes that shares ectodermal dysplasia and deformities of the hands and feet. Teratology, 11: 227-242.

Robinson G.C., Miller J.R., Bensimon J.R. 1962. Familial ectodermal dysplasia with sensorineural deafness and other anomalies. Pediatrics, 30: 797-802.

Rosselli D., Gulienetti R. 1961. Ectodermal dysplasia. Br. J. Plast. Surg., 14: 190-204.

Rubin A. 1967. Handbook of congenital malformations. Philadelphia: W.B. Saunders Co.

Salomon L.M., Esterly N.B. 1973. Neonatal Dermatology. Philadelphia: W.B. Saunders Co.

Samuelsen G. 1970. Hereditary ectodermal dysplasia. Report of two cases. Acta Paediatr. Scand., 59: 94-99.

Schnyder U.W. 1967. New findings in the ichthyosis and epidermolysis group. Proc. 3rd Int. Congr. Hum. Genet., Chicago 1966 [pp. 447-454]. Baltimore: Johns Hopkins Press.

Settineri, W.M.F. 1974. Estudos Genéticos e Clinicos em uma Forma de Displasia Ectodérmica. M. Sc. thesis, Federal Univ. of Rio Grande do Sul, Brazil.

Siemens H.W. 1921. Arch. Dermatol. Syph., 136: 69. Cited by Franceschetti 1953.

Smith D.W. 1969. Recognizable patterns of malformations in childhood. First Conf. Clin. Delineat Birth Defects. Part 2: Malf. Syndr. [pp. 255-272]. Birth Defects, Orig. Artic. Ser., vol. 5, no. 2.

Smith D.W. 1970. Recognizable Patterns of Human Malformation. Genetic, Embryologic, and Clinical Aspects. Philadelphia: W.B. Saunders Co.

Touraine A. 1932. L' " anidrose avec hypotrichose et anodontie" (polydysplasie ectodermique héréditaire). Presse Med., 44: 145-149.

Touraine A. 1952. Les états héréditaires d'atrophies cutanées avec sénescence prématurée. Ann. Dermatol., 79: 446-451.

Upshaw B.Y., Montgomery H. 1949. Hereditary anhidrotic ectodermal dysplasia. A clinical and pathologic study. Arch. Dermatol. Syph., 60: 1170-1183.

Weech A.A. 1929. Hereditary ectodermal dysplasia (congenital ectodermal defect). A report of two cases. Am. J. Dis. Child., 37: 766-790.

Witkop C.J., Brearley L.J., Gentry W.C. 1975. Hypoplastic enamel, onycholysis, and hypohidrosis inherited as autosomal dominant trait. A review of ectodermal dysplasia syndromes. Oral Surg., Oral Med., Oral Pathol., 39: 71-86. 


\section{RIASSUNTO}

\section{Nuova Rassegna delle Displasie Ectodermiche}

Viene presentata una visione storica dello sviluppo del concetto di displasia ectodermica. Cinque « definizioni » correnti vengono analizzate e 52-57 displasie ectodermiche vengono classificate in sottogruppi in base a criteri elaborati dall'autore.

\section{RÉSUMÉ}

Nouvelle Revue des Dysplasies Ectodermiques

Une vision historique du développement du concept de dysplasie ectodermique est présentée. Cinq définitions courantes du groupe sont analysées et 52-57 dysplasies ectodermiques sont classifiées en sousgroupes sur la base de critères développés par l'auteur.

\section{ZUSAMMENFASSUNG}

Neue Übersicht über die Ektodermalen Dysplasien

Geschichtliche Übersicht über die Entwicklung des Konzepts der ektodermalen Dysplasien. Analyse von fünf geläufigen «Definitionen ». Aufteilung in Untergruppen von 52-57 ektodermalen Dysplasien nach von dem Verfasser ausgearbeiteten Kriterien.

Prof. Newton Freire-Maia, Departamento de Genética (UFPr), Caixa Postal AA, 80000 Curitiba, Paraná, Brasil. 